\title{
A Study of Good Governance Innovation of Javanese Leadership in Indonesia
}

\author{
HERMINI SUSIATININGSIH ${ }^{1}$, BUDI SETIYONO ${ }^{1}$, SHEIFFI PUSPAPERTIWI ${ }^{2}$, \\ JUMADIL SAPUTRA $^{3, *}$, TEUKU AFRIZAL ${ }^{1}$ \\ ${ }^{1}$ Faculty of Social and Political Science \\ Universitas Diponegoro \\ Tembalang, Semarang, 50275 Jawa Tengah \\ INDONESIA \\ ${ }^{2}$ Coordinating Ministry for Economic Affairs \\ DKI Jakarta 10710, Jakarta \\ INDONESIA \\ ${ }^{3}$ Faculty of Business, Economics and Social Development \\ Universiti Malaysia Terengganu \\ 21030 Kuala Nerus, Terengganu \\ MALAYSIA
}

\begin{abstract}
In developing countries, the government faces many problems related to good governance. Also, there is a lack of understanding of good governance innovation. Thus, this study focuses on the local context. In practice, many developing countries take the notion of good governance for granted, therefore it without critical views. This situation leads to the gap between expected outcomes and realization, which cause the sub-optimal implementation of good governance. Of these, the present paper argues that the implementation of good governance innovations by considering the theory or ideology context. The design of this study is a qualitative study through systematic literature review analysis. Two factors are influencing the success of good governance innovations, namely leader and leadership in Javanese culture. The result of this study found that the success of good governance innovation is supported by the existence of leaders and leadership style which conform to Javanese culture and philosophy. In conclusion, the output embodies the notion of good governance; the process is a unique combination of good governance and local wisdom, which is Javanese philosophy.
\end{abstract}

Key-Words: Good governance, innovations, Javanese culture and leaderships.

Received: December 1, 2020. Revised: March 31, 2021. Accepted: April 7, 2021. Published: April 14, 2021.

\section{Introduction}

The introduction of good governance practice in the late 1980s has brought a significant impact on public policy practices and academic discourses. Derived from Western countries' experiences in developing their socio-economy, international organizations promoted governance through development projects implemented in partner countries. The idea of governance used to solve every problem faced by the government or state across the world, especially developing countries. This action implied a notion that governance was "good" and "preferred" to achieve "development" and "prosperity", thus need, or even obliged, to be followed by partner countries wished to achieve development level as the Western countries had. It is also the reason why developing countries believe that governance, later known as good governance, as a prerequisite of public welfare. Departing from the normative view of governance promoted by international development organizations, more critical perspectives on the notion of good governance emerged from academic discourses. In a crucial viewpoint, the governance uses international developmental organizations to push structural reform in partner countries, which by scholars [1] and [2], seen as an attempt to liberalize domestic polity of respective countries. Academic discourse also recognized the gap between expectation and outcome of these programs. $[1],[3],[4],[5]$ and [6], agreed that governance was not merely a set of principles, but rather a long process which acknowledged context as contributing 
factors. Their studies started to identify the importance of context in implementing good governance, by arguing that the existence of local people, local context, and local cultures do matter. This critical view of good governance gains more supports from scholars as it is better in explaining the reality where different situations and problems faced by countries.

As a partner country of international development programs itself, Indonesian is no exception in the case of countries which view good governance as the panacea of its problems. Government, both at the national and local levels, also often fall into simplifying the notion by ignoring context where local culture and tradition take place. The government often does not carefully recognize that context, in terms of practice, local people, and the location is pivotal in innovation. In this paper, we convey our belief that good governance is essential for the national and local governments in the context of its implementation. It refers to the place, time bonded as well as local cultures and surrounding environments.

In this study, we focus our discussion on the local culture, especially related to leader and leadership, in Javanese regions. This study takes examples in three cities: (1) Surakarta under Mayor Joko Widodo (2005-2012), (2) Kulonprogo under Regent Hasto Wardoyo (2011-2019), and (3) Surabaya under Mayor Tri Rismaharini (2010-2020), where leaders implemented innovative programs to improve public welfare. Also, we elaborate on the concept of good governance and the importance of context in its implementation. We discuss the notion of leader and leadership in Javanese philosophy, highlighting the significance of the leader's position in Javanese society and explain on how the selected leaders implement good governance in innovation programs to support our main argument. This paper is concluded by s conclusion, where we iterate our key findings and give our inferences.

\section{Methodology}

This study employs a qualitative approach. It aims to achieve the research objective. To understand the importance of context in implementing good governance. We propose three goals in this study. First, we investigate existing works of literature to find the importance of context in implementing good governance. Second, we identify critical doctrines of Javanese leader and leadership philosophy, as a background to understand the context in the following stage. Third, we explore the result of preceding steps in selected Javanese regions which already known for their successful innovation programs: Surakarta under Mayor Joko Widodo,
Kulonprogo under Regent Hasto Wardhoyo, and Surabaya under Mayor Tri Rismaharini. This study emphasized on two factors, namely leader and leadership, as Javanese culture acknowledges important roles of these two notions in understanding society. Based on the steps taken, we finalize our arguments on the importance of considering the context in good governance implementation.

\section{Results and Discussion}

\subsection{The Concept of Good Governance}

In the late 1980s, the notion of governance has been widely discussed and given meaning. It may refer to the practice of management in the private sector, international relations, political science, and government studies. In early government studies, governance refers to the definition by [7]. In its report, governance defines as the exercise of political power to manage national affairs [7]. However, this definition was perceived as too broad so that in 1992 the institution made narrower definition by stating: Governance is epitomized by predictable, open and enlightened policymaking (that is transparent processes); a bureaucracy imbued with a professional ethos; an executive arm of government accountable for its actions, and a strong civil society participating in public affairs and all behaving under the rule of law [7].

While World Bank's definition implied that governance as a matter of government performance output, development in academic writing shows scholars' preferences to see governance as a process by which a policy is implemented. [8] for instance, defines governance by stating that governance is "the process of decision-making and the process by which decisions are implemented (or not implemented)". In line with his view, [9] argues that governance is governing processes that cover not only the government but also other important factors such as the private sector and civil society.

[10] provides a more precise concept of governance by stating that "governance is about the rules of collective decision making in settings where there is a plurality of actors or organizations and where no formal control system can dictate the terms of the relationship between these actors and organizations". Based on their definition, we know that governance comprises of four elements. The first element rule, either formal or informal, as the rule of the game in policymaking. The second element is collectiveness, which refers to collective actions in which no one can determine or dictate the process, including the government. The third element is policymaking, which refers to the question of by 
whom the policy is made, how many actors involved, and whether the policy made is accountable or not. The fourth element is equity; namely, no one can formally control the relationship between actors involved in policymaking Equity may cover both formal and informal factors involved through negotiation, specific political signal, sovereignty, or communication.

Based on the explanation mentioned above, we can note that governance is not only referring to policymaking but also to various kinds of relations among stakeholders (public, private or civil society actors) in which formal or informal interaction may take place. Studying governance is, therefore, not only focusing on a list of successful governance performance but also a process by which the governing and interaction among actors take place. This paper subscribes to the meaning and the context of governance, as stated here.

\subsection{Good Governance Perspectives}

The study of governance started relatively new in academic discourse. The early discussion was referred to as the experience of African governance practices when these countries received funding from the World Bank to practice good governance. The term "good" in governance used to facilitate the reality where the practice of Africa governance was poorly implemented. Therefore, the Bank initiated the word "good" to replace the practice of bad governance in Africa.

Based on literature and discussion development on its practices and theories, we can divide the study of good governance into two mainstream perspectives, namely normative and academic. The normative perspective on good governance focuses its analysis on something "good" that must be promoted in developing countries. The normative perspective refers to international development institutions such as the World Bank, International Monetary Fund (IMF), and the United Nations Development Program (UNDP). In its latest discussion, the World Bank defines good governance as:

"The tradition and institutions by which authority in a country is exercised. It includes (a) the process by which governments are selected, monitored and replaced: (b) the capacity of the government to effectively formulate and implement sound policies: and (c) the respect of citizens and the state for the institutions that govern economic and social interactions among them [7].

Moreover, the World Bank mentions six main characteristics of good governance, namely (1) voice and accountability, (2) political stability and absence of violence, (3) government effectiveness, (4) regulatory quality, (5) the rule of law, and (6) control of corruption. Like the World Bank, IMF clarifies the meaning of good governance as:

"improving the management of public resources through reforms covering public sector institutions (e.g. the treasury, central bank, public enterprises, civil service, and the official statistics function), including administrative procedures (e.g. expenditure control, budget management, and revenue collection); Supporting the development and maintenance of a transparent and stable economic and regulatory environment conducive to efficient private sector activities (e.g. price systems, exchange and trade regimes, and banking systems and their related regulations [11].

This IMF definition may confirm that good governance is not only about the government, but also good practices in private sectors such as efficiency, accountability, and transparency. Meanwhile, the academic perspective refers to scholars' attention to the study of good governance subjects. This perspective stresses analysis on a deeper concept of good governance, and quite often, takes a critical view from the former perspective. For example, [1] and [2] criticize the normative perspective by saying that there is an ideological agenda behind good governance projects in developing countries. Liberal ideology is suspected as a hidden agenda when the institutions offer cooperation through good governance-based projects to developing or least developed countries.

They argue that local context and cultures must be taken into consideration when implementing good governance project. Scholars [1],[3],[4],[5] and [6] agree that good governance is not only about a list or a characteristic. They believe that good governance is a long dynamic process behind the process of becoming good. They also argue that good governance is not a simple process since it must pay attention to the existence of local people, local context, and local cultures. [6] sees good governance as:

"Good enough governance means that interventions thought to contribute to the ends of economic and political development need to be questioned, prioritized, and make relevant to the conditions of individual countries. They need to be assessed considering historical evidence, sequence, and timing and they should be selected carefully in terms of their contributions to ends such as poverty reduction and democracy. Good enough governance directs attention to the minimal conditions of governance necessary to 


\section{allow political and economic development to} occur",.

[6] clarifies the significance of conditions for individual countries, historical evidence, and political timing. It implies that implementing good governance in different countries must use other methods as well. Therefore, good governance is not a panacea that fits for all. Meanwhile, [12] provides an excellent explanation of good governance by arguing that there are five main propositions of good governance, namely:

1) governance refers to a complex set of institutions and actors that are drawn from but also beyond government; 2) governance identifies the blurring of boundaries and responsible for tackling social and economic issues; 3) governance identifies the power dependence involved in the relationships between institutions involved in collective action; 4) governance is about autonomous self-governing networks of actors; 5) governance recognizes the capacity to get things done which does not rest on the power of government to command or use its authority".

[12] concept of good governance puts a clearer point that good governance is a complex one, in terms of different actors, different interests, and different methods in making public policies. There is a lot of things happen in the process of governing, whether formally or informally. Based on this meaning, we can conclude that good governance is not a simple process that takes developed countries' experiences for granted to be implemented in countries with different social, economic, and political standing.

\subsection{Determinant Factors of Good Governance}

Since good governance is a complex notion, it leads to the question of what are then determining factors of successful good governance? Theoretically, several pivotal factors are determining the success of good governance, namely (1) leadership, (2) institutional reform, (3) public sector modernization, (4) organized civil society and (5) tradition and democratic cultures [5],[6],[13] and [14].

Leadership, according to [6],[13],[14] and Babajanian (2008), play an important role in the success of good governance achievement. Leadership determines the direction or objectives of reform. Good leadership will make it simple in achieving the governing process to get the goals. To be specific, [6] mentions that entrepreneurship leadership is pivotal in determining the success of governance.

Institutional reform is also the main factor in determining good governance achievement, according to [13], [14] and [15]. Institutional reform may take place in terms of structural, institutional, and cultural reforms that are conducive to achieve good governance. Structural reform may be related to a new structure of the organization and provide enough authority to the institution to do their job well. Institutional reform refers to organizational changes such as reforms in management functions (planning, implementing, and evaluating system) or supporting resources such as finance or infrastructure. Cultural reform is dealing with human resource behaviour that is supported to achieve good governance practices.

Public sector modernization determines the success of good governance according to several experts such as [6] and [13]. Public sector modernization includes three important changes, namely the implementation of new ideas, new technology, and new training. New ideas, technology, and training may speed the process up in achieving good governance objectives.

Organized civil society is also an important factor in determining good governance. [6] and [14] clarify that critical and organized civil society may influence the success of good governance. Critical organized civil society is indicated by active and supportive participation as well as an intensive social control to the governance process.

Finally, tradition and democratic cultures are also key factors to determine the success of good governance. [5] include the several elements, namely tradition of social agreement, egalitarian culture, democratic and participative cultures. [6] mentions that competitive elections as a democratic culture are important to achieve good governance. [1] argues that Western culture can be used as guidance to democratize developing countries. On the other hand, developing countries may have their own cultures which in line with Western liberal democratic cultures.

\subsection{Leadership in Javanese Culture}

Javanese is the biggest culture group in Indonesia, consisting of about 38,8 per cent of the Indonesian population in 2019. [16] identified Javanese as those who (1) speak Javanese language and still hold Javanese culture or way of life and (2) explicitly try to live based on Islamic principles. [17] argues that Javanese are those who live in the cultural region of Java which consists of all parts of central and eastern Java. [18] states that Javanese society is the unity of Javanese people who interact based on Javanese customs, norms, and culture system and bounded by a collective identity as Javanese. [19] then mentions "Javanism" as Javanese way of life is guided by the notions of spiritual serenity, harmony, and balance, and accepting to all events while reminding that 
individual position is below society, and society is below universe.

Harmony and order are the basic principles in Javanese morality. The Javanese perceive that maintaining harmony in society is a noble social obligation, thus placing collectivity above individuality. However, Javanese are not an egalitarian society because they believe in the hierarchy to maintain order. Priyayi (nobility), Bandara (master), and wong cilik (commoner) are expected to serve different moral and social roles based on class structure. They have different functions in society, and each position holds different hierarchical status, which becomes the basis of their social interaction in society. Javanese philosophy believes that it is important for any individual to perform roles as prescribed for them based on their social positions. Because only by doing so, society will be able to maintain order to achieve and sustain harmony as the ideal of society [19].

Javanese life is characterized by ceremonial and symbol. The Javanese believes that ceremony is required to formalize important events in their life [19]. The extensive tradition of ceremonies in Javanese culture is deeply related to their belief of symbols, in which those symbols represent sacred values or wishes to the respected events. For instance, Javanese holds Ruwahan ceremony to welcome the holy month of Ramadhan. [19] states that the ceremonial trait in the Javanese way of life represents a deeper meaning of their philosophy. As Javanese puts a great significance for form, they believe that form is more important than content and thus determines content yet reality. It implies that the Javanese accept structure as given, thus becomes their obligation to obey and put their best efforts to materialize the ideal form.

As the social interaction of the Javanese is based on hierarchical order, it is implied that society, or individual, needs guidance or help from above to solve problems. Javanese people are known to prefer listening to their leaders than making their own decision, as they wish to be perpetually protected and led by their leaders. The Javanese are keen to be led and able to adapt with the leader, as ngeli (following) and nrimo (acceptance) are perceived as noble moral values. Javanese also tend to believe in people and rank, more than abstract ideas or [18].

On the other hand, Javanese culture placed great responsibility on leaders. Leaders are expected to hamangko (take responsibility for their duties), hamengku (do their duty well), and hamengkoni (protect people in all situations). Other Javanese philosophy which also teaches leadership can be found in ing ngarsa sung tuladha, ing madya mangun karsa, tut wuri handayani. Based on this philosophy, leaders should be able to give example in front of their peoples (ing ngarsa sung tuladha), while always give support especially in hard times when being among people (ing madya mangun karsa), and motivate (give push from the back of) people to pursue progress (tut wuri handayani). When leaders can perform those moral duties and do the right things for the society, people will give their supports to the leaders and their decisions, thus protect their legacy or achievement (melu handarbeni, melu hangrungkebi, mulat sarira hangsara wani) [20].

\subsection{Government Sector Innovation: The Importance Context of Indonesia}

Indonesia can learn from several local governments that succeeded in implementing good local governance. The example of good governance implementation of local governments found in Surakarta, Kulonprogo, and Surabaya. In these three local governments, good governance has been implemented in innovation programs run by the leader. While the principles of programs adopted best practices from developed countries' experiences, these leaders used different methods in the process to emulate local context. Later, these approaches proved to be successful cases where innovation in public administration based on good governance gained massive supports from the public. Itwas where the notion of leader and leadership in Javanese culture took place, as the three leaders succeed to perform Javanese style leadership and gained support from their Javanese-dominated populations.

Implementation of good governance in these three cities shows that consideration of context is important to make sure that city innovation or reformation can take place effectively. One key success of good governance implementation in these cities or local governments is the good leader-people relationship in each leadership. Good leadership, or Javanese leadership in these cases, plays a significant role not only in the output of innovation but also in the process of innovation itself. The presence of cultural related leadership style has made it easy for the innovation programs to be implemented in respective regions.

\section{The Lesson from Surakarta}

Surakarta under Joko Widodo (popularly known as Jokowi) - FX Rudy Hadyatmo from 2005-2012 showed significant progress in terms of good governance innovation and implementation. Jokowi, as the mayor of Surakarta tried to implement good governance innovation by implementing the private sector model of management into the public sector of 
Surakarta City. On many occasions, Jokowi always stressed the importance of professional standards as well as service quality in managing city public affairs.

There were several notable innovations implemented during Jokowi-Rudy terms. For instance, prompt and professional standard of services in Badan Pelayanan Satu Atap (one-stop service office), the importance of participation in the city policy process, as well as the significance of transparency and accountability in managing city policy and finance. The success of developing local street vendors (pedagang kaki lima, PKL) in Surakarta city by relocating them to a newly established place was an excellent example of local government innovation in the participation aspect.

Innovation in participation was implemented by Jokowi-Rudy through intensive communication, both formally and informally to socialize the intention and benefit of the program. In the case of PKL relocation, the leaders actively communicated with the street vendors about the merit of the program and listened to their aspirations. The active communication then made the PKL realized that the program was not about removing their business, but rather empowering the PKL, thus agreed to the relocation. Based on this case, it is worth noting that building trust between the local government and PKL association is a crucial step to make the proposed program successful.

By looking into those programs, we find four main principles of good governance which were implemented by Jokowi-Rudy local government. These four main principles are participation, transparency, accountability, and the rule of law. A good participation process, as shown in the case of the PKL relocation program. Transparency, accountability, and the rule of law were well implemented in managing local finance, particularly in building and upgrading traditional market revitalization. In this program, the traditional market was not destroyed but developed and revitalized.

While successfully innovating public affairs trough implementing good governance-based programs, it is important to note that the success was strongly supported by leadership capacity to implement good governance in the local context of Surakarta city. Jokowi-Rudy was known for using informal methods to make sure that innovation can take place successfully in the city context. In Javanese culture, people believed that they should respect and obey their leaders, especially when the leaders perform good intentions and examples for them. Jokowi and Rudy took this philosophy by becoming leaders who could be trusted by the people, which gained by actively communicated with their people. Been among the people, Jokowi and Rudy showed their quality as leaders by showing their respect and support for their people or also known as nguwongke. Reciprocally, the people conformed the Javanese notion of ngeli and nrimo, as they believed that their leaders knew what was best for them.

\section{The Lesson from Kulonprogo}

Practices of good governance innovation in Kulonprogo, Yogyakarta was unique. Under Regent Hasto Wardoyo, Kulonprogo which was not well known before his term, then immensely popular because of his capacity to innovate governance reform at the local level. Hasto Wardoyo innovation widely discussed the success of implemented programs to boost the independent spirit in developing the local economy, named Program Bela Beli Kulonpogo (Fight and Buy for Kulonprogo Program). The program aimed to make residents maintain and proud of being Kulonprogo people. Based on this program, they instructed to use or buy local products of Kulonprogo. By consuming the local product, Kulonprogo people could make a real contribution to the economy of the Kulonprogo Regency, thus helped it to thrive in the era of economic openness.

There were several main innovations implemented to achieve good local government. Firstly, innovating regional economic power by instructing people of Kulonprogo to buy only local products, such as local water or clothes (Batik Geblek Renteng). On the other hand, Regent Hasto Wardoyo asked local water public corporation (Perusahaan Daerah Air Minum - PDAM) to produce their drinking water which must be used in all public offices in Kulonprogo. This program has been successful in improving Kulonprogo branding and economy since the local government owns the PDAM. Local public officers also required to wear local batik to empower local batik industries. This local batik program was also successful as part of Kulonprogo's local government innovations.

Secondly, a program called the empowerment of Kulonprogo local farmers. Regent Hasto instructed Kulonprogo public officers to buy rice produced by local farmers. Under the program, Kulonprogo public officers must buy $10 \mathrm{~kg}$ of rice per month from Kulonprogo's farmers. It was intended to support the economy of the local farmers, as they got sustainable demand for their products at the appropriate price. Through this program, Regent Hasto expected that the farmers, who usually became the marginalized in economic development, could also enjoy the fruits of development. 
Thirdly, Kulonprogro established a program called bedah rumah or building local facilities or infrastructure in which the raw material such as cement, sand, brick, or asphalt must originally come from the local products. As a result, the local business could grow productively and able to improve the economic power of the people. Fourthly, Kulonprogo improved health programs while refusing cigarette advertisements in all areas of the regency. Regent Hasto refused to use cigarette companies to develop the regency and preferred to develop health assistance for the poor by providing full health cover or facilities to the needy local people. This program was successful and beneficial for the poor people in Kulonprogo Regency.

These innovation programs of the Kulonprogo Regency under Hasto Wardoyo showed that local people, local situations, and local context of the regency were determinants of the successful implementation of good governance innovation. These programs are in line with Javanese philosophy melu handarbeni, melu hangrungkebi, mulat sarira hangsara wani. Emphasis on melu handarbeni refers to the fact that people give their supports because the leader performed the moral duty to protect local businesses, especially the marginalized (the farmers). The role of protection was also performed by the Regent by banning cigarettes advertisement, as the detrimental health effect of cigarettes has been widely known. The Regent also provided affirmative protections such as public health facility and infrastructure facility for the poor, reflecting his ability to be just (adil) with different needs of his people. The second emphasizes melu hangrungkebi, which is best shown in Program Bela Beli Kulonprogo. The program, which aimed to empower local businesses, improved people's sense of belonging to local economic development because they have been included in the economic activity. Based on these two notions, it was not a surprise if Regent Hasto's innovation programs gained wide supports from Kulonprogo people.

\section{The Lesson from Surabaya.}

Surabaya is also one good example of good governance innovations in the Indonesian local government system. The leadership of Mayor Tri Rismaharini (popularly known as Risma) becomes the key success of good governance innovation in Surabaya. Risma is seen as one successful mayor in the world, because of her capacity in developing, empowering, and innovating good local governance. In developing Surabaya City, Mayor Risma uses not only participation, which is one of the important good governance principals, but also involvement. Mayor
Risma is actively involved in public affairs, not only at the high level but also join the grassroots activity. She is often seen joining many events in public such as city cleaning programs, firefighter team, and so the like. For her public, Mayor Risma is not only working at the office but also does not hesitate to jump directly in the society to help and protect them.

There several main innovation programs in Surabaya city, namely improving environment quality and assisting poor people. The first innovation program was a great success as Surabaya City is now well known for its green cities equipped with many green parks and well open space facilities. The existence of new green parks is believed to reduce pollution and lower the city's average temperature, thus improving the environment and living quality of its citizen. The second program is poor people empowerment. In this program, Mayor Risma provides facilities and assistance to help them survive in this metropolitan city. The mayor empowers informal workers, dropped out students, and others to work and survive in the city.

Based on the Surabaya experience, it confirmed that the innovation of good governance must pay great attention to the context of the city. In terms of Surabaya, local people's participation and involvement are key factors of innovation programs' success. As a leader, Mayor Risma lives the Javanese philosophy of ing madya mangun karsa. She shows that active participation and involvement of leaders in the middle of the people is important to build trust and thus generates participation and involvement from the people. By presenting herself among her people, she becomes the motivation for the Surabaya people to do better for their city development. Her presence among her people also becomes a significant gesture (symbol) that she is there to give protection to her people. These actions perceived as what makes her a good leader in Javanese culture, thus enable her to gain support for innovation programs implemented in the city.

\section{Conclusions}

Good governance focuses on indicators to measure outputs. Studies have been dominated by questions on how to measure good government performance indicators, such as those which have been widely conducted by international development organizations such as the World Bank, IMF, UNDP, $\mathrm{ADB}$, and so forth. By then, good governance turns as if it is just a mere checklist of characters and losing its meaning, thus its significance. We believe that good governance has more value than that, which makes us shift our attention to the interaction of 
actors who involved in the process of governance and thus derive some meaning of its implementation. This paper subscribes to the idea that good governance is an important element in innovating government, both national and local levels. We argue that implementing good governance, if hoping to succeed, must consider the significance of context, whether it is the place, people and or culture.

As our study in the Javanese context, the success of good governance innovations is strongly influenced by leaders and leadership. From a good governance perspective, leaders and leadership are needed to promote change in the system or mechanism where the innovation process takes place. Further from our study, we find that leader and leadership are critical determinants since Javanese society works in hierarchical order to maintain harmony. Javanese philosophy taught people to listen and support their leaders, especially when they can conform to cultural norms and values. Our findings from the three cities support the argument that context does matter in good governance implementation.

As a norm in development, we can agree that good governance is universal in terms of its values. However, we should put context to understand the notion better, which can vary in different countries, even regions. As a universal value, we find that while good governance implementation's output may be a similar one to another, the process may be a unique mixture of good governance and local wisdom, thus may vary depends on its context. Furthermore, though we find that leader and leadership are crucial in the success of good governance implementation, we believe that change toward good practices of governance should not only be focused on the actor, but also on the system to guarantee its sustainability.

\section{References:}

[1] Leftwich, A. (1993). Governance, democracy, and development in the Third World. Third World Quarterly, 14(3), 605-624.

[2] Hadiz, V. R. (2004). Decentralization and democracy in Indonesia: A critique of neoinstitutionalist perspectives. Development and change, 35(4), 697-718.

[3] Rhodes, R. A. (1997). Understanding governance: Policy networks, governance, reflexivity, and accountability. Open University.

[4] Stoker, G. (2018). Governance as theory: five propositions. International Social Science Journal, 68(227-228), 15-24.
[5] Pierre, J \& Peters, G. (2000). Governance, politics, and state. Hounds Mills, United Kingdom: Macmillan.

[6] Grindle, M.S. (2007). Going local: decentralization, democratization, and the promise of good governance. Oxford: Princeton University Press.

[7] World Bank. (1997). World Development Report 1997: the state in the changing world. New York, United States of America: Oxford University Press.

[8] Evans, J. (2012). Environmental governance. United Kingdom: Routledge.

[9] Davis, G \& Keating, M. (2000). The future of governance. New South Wales, Australia: Allen and Unwin.

[10] Chhotray, V. \& Stoker, G. (2009). Governance theory and practice: a cross-disciplinary approach. Hampshire, United Kingdom: Palgrave Macmillan.

[11] International Monetary Fund. (1997). Good governance: the IMF's role. Retrieved December 18, 2019, from http://www.imf.org.

[12] Stoker, G. (1998). Governance as theory: five propositions. International social science journal, 50(155), 17-28.

[13] Dudley, G \& Richardson, J. (2000). Why does policy change? lessons from British transport policy, 1945-1999. New York, United States of America: Routledge.

[14] Sumarto, H. S. (2009). Inovasi, partisipasi dan good governance: 20 prakarsa inovatif dan partisipatif di Indonesia. Jakarta, Indonesia: Buku Obor.

[15] A Pierre, J \& Peters, G. (2000). Governance, politics, and state. Hounds Mills, United Kingdom: Macmillan.

[16] Magnis-Suseno, F. (1997). Javanese ethics and worldview: the Javanese idea of a good life. Jakarta, Indonesia: Gramedia.

[17] Kodiran. (1975). Kebudayaan Jawa. In Koentjoroningrat (Ed.) Manusia dan kebudayaan di Indonesia. Jakarta, Indonesia: Djambatan.

[18] Siswanto, D. (2010). Pengaruh pandangan hidup masyarakat Jawa terhadap model kepemimpinan: tinjauan filsafat sosial. Jurnal Filsafat 20(3): 197-216.

[19] Mulder, N. (1973). Kepribadian Jawa dan pembangunan nasional. Yogyakarta, Indonesia: Gadjah Mada University Press.

[20] Hudaya, A. Z., \& Nugroho, S. W. D. (2013). Kearifan lokal budaya jawa sebagai basis model kepemimpinan yang efektif. Jurnal dan prosiding FEB Unsoed 3(1), 1-8. 


\section{Contribution of individual authors to} the creation of a scientific article (ghostwriting policy)

Hermini Susiatiningsih writing - original draft and investigation.

Budi Setiyono writing - methodology and supervision.

Sheiffi Puspapertiwi writing - methodology and supervision.

Jumadil Saputra writing - review and editing, methodology and analysis.

Teuku Afrizal writing - review and editing and data analysis.

\section{Sources of funding for research} presented in a scientific article or scientific article itself

We would like to thank Universiti Malaysia Terengganu which has supported this research publication and one form of research collaboration with Universitas Diponegoro (UNDIP)

\section{Creative Commons Attribution}

\section{License 4.0 (Attribution 4.0}

\section{International, CC BY 4.0)}

This article is published under the terms of the Creative Commons Attribution License 4.0

https://creativecommons.org/licenses/by/4.0/deed.en _US 